\title{
CRIMINAL RESPONSIBILITY OF BUSINESS AGENTS ON SELEBGRAM'S (CELEBRITY ENDORSERS) PRODUCT PROMOTION
}

\author{
Nynda Fatmawati Octarina \\ Faculty of Law - Narotama University Surabaya \\ Ninda.fatmawati@narotama.ac.id \\ Tahegga Primananda Alfath \\ Faculty of Law - Airlangga University \\ taheggaalfath@gmail.com \\ Anisatul Ulfa \\ Narotama University Surabaya \\ Anisatululfa17@gmail.com
}

\begin{abstract}
Product promotion on Instagram by selebgram (celebrity endorser), Instagram users who have voluminous followers, is increasingly popular. It is not uncommon that the promoted products are sometimes not legally registered and possibly violate the law. This study analyses the regulations regarding promotion on social media in Indonesia as well as evaluates whether existing regulations govern business agents' criminal Responsibility for their carried-out promotions on Instagram, as seen from the fact that such product promotion content made by selebgram has misleading information resulting consumers' losses. The research method used is a legal research method with a regulatory approach and legal concepts. The result of this study indicates that if a business agent uploads a video which is misleading and potentially disadvantages consumers made by a selebgram, then the business agent is responsible for the upload. On social media, every user is responsible for their own account's activities.
\end{abstract}

\section{Keywords: Criminal Responsibility, Business Agents, Selebgram}

\section{INTRODUCTION}

In the current era of globalization, people are jointly pursuing technological developments. The rapid advancement of technology enables people to interact without directly meeting face to face. ${ }^{1}$ Technology not only facilitates interaction, but trading is also widely influenced by its sophistication. One of them is the use of social media as a promotional media to increase profits. Social media is a tool or software that facilitates a group to gather, share, collaborate, and play together. ${ }^{2}$ Social media has the following characteristics ${ }^{3}$ :

1. Social media as a means of delivering news to the public

2. Information conveyance is unlimited because it does not go through a particular institution, so there is no 'filter' before submitted to the community \footnotetext{
Pg. 1

${ }^{1}$ Niniek Suparni, 2009, Cyberspace Problematika dan Antispasi Pengaturannya, Sinar Grafika, Jakarta,

${ }^{2}$ Christian Fuchs, 2014, Sosial Media: A Critical Introduction, British Library, Pg. 32

${ }^{3}$ Nynda Fatmawati Octarina, 2018, Pidana Pemberitaan Media Sosial, Setara Press, Malang, Pg. 60
} 
3. The process of delivering information does not require much time.

The use of social media empowers the more uncomplicated information exchange. As explained by Andreas Kaplan Michael Haenlein, social media is a group of internetbased applications that allows the transfer of information (user-generated content). ${ }^{4}$ Various business doers, including those who work in SMEs (Small and medium enterprises) or MSMEs (Micro Small and Medium Enterprises) as well as the ones who don't have official licenses, gain advantage from social media. The reason is promoting in social media is more enticing. The internet-based advertisement aims to disseminate information, create awareness, research objectives, create perceptions, trial products, improve services, and improve distribution. ${ }^{5}$

This study discusses product advertising with Celebrity endorser (Selebgram) as it is known that Instagram is one of the five most popular social media in Indonesia. Five popular social media used to carry out online shop promotion are Facebook, Instagram, Twitter, YouTube, and Pinterest. Instagram is the second best social media suitable for online trade-in Indonesia. It enables people to reach the desired market with the minimum budget by creating an advertisement.

Although profitable, the use of the internet may trigger cybercrime. Initially, cybercrime is defined as computer crime. In the past, Indonesian scholars used several terms such as "computer misuse", "computer abuse", "computer fraud", and "computerrelated crime" to define this. Finally, they decided to use a similar term, "computer crime", considering that this term is more popular and widely used in international relations. ${ }^{6}$

Mandell divides "computer-crime" into 2 activities: ${ }^{7}$

1. The usage of computers as a tool used for fraud, stealing and hiding to gain profit or wealth.

2. Threats of violence such as theft of hardware or software, sabotage, and extortion

At the early stage of cybercrime, scholars focused on the hardware of computers. The technology development, which gives birth to the internet, has expanded the focus of cybercrime increasingly. Today, cybercrime is not only targeting hardware but also social networking or cyberspace. ${ }^{8}$ Thus, cybercrime covers all criminal offenses relating to information systems and whatsoever used as a means of storing and exchanging information (transmitter/originator to the recipient). ${ }^{9}$

Crimes involving technology essentially cause massive losses. Unlike conventional crime, whose losses can be calculated, and the criminal existence can be localized, cybercrime enables the offenders and victims not to be at the same time. So, the offenders are hardly localized, and the losses are limitless. Therefore, it is necessary to avert, such as crime, preventively and repressively. ${ }^{10}$

\footnotetext{
${ }^{4}$ Andreas M. Kaplan, User of The World, Unite! The Challenges and Opportunities of Sosial Media. Business Horizons, vol. 53 no. 1 edisi 2010, pg. 59-68

${ }^{5}$ Morisan, 2010, Periklanan komunikasi pemasaran terpadu, Penerbit kencana, Jakarta.

${ }^{6}$ Puslitbang Hukum dan Peradilan (Agency for Research and Development and Education and Training in Law and Justice) Supreme Court of Indonesia, 2004, Naskah Akademis Kejahatan Internet (Cybercrime), pg. 4

${ }^{7}$ Ibid., pg. 10

${ }^{8}$ Budi Suhariyanto, 2014, Tindak Pidana Teknologi Informasi (Cybercrime), PT Raja Grafindo Persada, Jakarta, pg. 11

${ }_{9}^{9}$ Didik M. Arief Mansur dan Elisataris Ghultom, 2005, Cyber Law-Aspek Hukum Teknologi Informasi, Refika Aditama, Bandung, pg. . 10

${ }^{10}$ Budi Suhariyanto., op.cit, pg. . 44
} 
Product Promotion on Instagram done by Celebrity endorsers (Selebgram) is one of the examples. Although such advertising contributes advantages, it occasionally has negative sides. One of them is the consumers' loss because of Selebgram's misleading advertisement. They usually create video or photo content. Selebgram's lack of awareness for product quality, the existence of BPOM (National Agency of Drugs and Food Controls) numbers, as well as product safety guarantees, can mislead and harm consumers. Unfortunately, the misleading promotional content in the form of photos and videos made by Selebgram is re-uploaded by business agents.

Based on the background outlined above, the issues to be examined in this study are: What is the form of regulation for product promotion on social media? Can the business agents be legally responsible for uploading Selebgram's product promotion on their accounts? After analyzing the formulation of the problems, this study aims to study the regulation of product promotion on social media and the criminal Responsibility of business agents for uploading selebgrams' product promotion.

This research is original; it focuses on the criminal Responsibility of business agents who hire selebgram to promote their products. Usually, to avoid criminal Responsibility, the business agents use the argument of not knowing the product or believing in the product promotion carried out by selebgram. Meanwhile, other researches discuss the accountability of selebgram for carried-out product promotion. Research conducted by Rahmania Fathorani in 2019 has similarities with this study. The title is" Analisa Yuridis Tentang Selebgram Sebagai Pelaku Usaha Periklanan" (Juridical Analysis of selebgram as Advertising Business Agents). This study examines the efforts that can be taken by consumers for selebgram's promotional advertisements. Can they be held accountable?

This study uses normative legal research methods with statue and conceptual approaches. The state approach allows this research to analyze the laws and regulations relating to advertising problems, information, and electronic transactions, as well as consumer protection. Afterword, the conceptual approach studies legal concepts related to criminal Responsibility, the idea of rights and obligations of business agents, and cybercrime.

\section{DISCUSSION}

\section{Regulations for Product Promotion on Social Media}

Before the establishment of ITE Law, the government was urged by two major powers to regulate cybercrime issues. The pressure comes from national and international demands. In the national level, it is important to deal with domestic cyber problems. Criminal Code and Criminal Procedure Code are insufficient in handling these kinds of crimes. Then, at the international level, Indonesia is expected to participate in combating global cybercrime. ${ }^{11}$

After the Law was established, new problems have emerged in the form of community compliance toward the law. Many new ascended cases have proven the difficulty of law enforcement. Law enforcement officials continue to look for ways to uphold the law in the existing community. However, another obstacle appears; the community is developing very fast, which increases the difficulty of enforcing the law. So, law enforcement is increasingly difficult as well. ${ }^{12}$

\footnotetext{
${ }^{11}$ Budi Suhariyanto., op.cit, pg. . 49

${ }^{12}$ Ibid., pg. . 78-79
} 
Unfortunately, this is intensified by the inability of existing regulations to cover all cases, which, in the end, burdens law enforcement to resolve those cases. The rapid development of a society becomes a problem because the absence of laws and regulations governing the certain arising problems. It is very unlikely a rule is used to solve a problem completely. In addition, if the cases are covered by no applicable law or legal vacuum. ${ }^{13}$

\section{Business Agents}

Before going to deeper and further discussion, it is necessary to understand the definition of business agents. Based on article 1 number 3 of Law no. 8 of 1999 concerning Consumer Protection, "A business agent is a person or a company, in the form of a legal or non-legal entity established and domiciled or engaged in activities within the legal territory of the Republic of Indonesia, conducting various kinds of business activities in the economic sector through contracts, both individually and collectively."

According to the experts, a business agent is either an individual or a company in the form of a legal or not legal entity, who conducts business activities in various economic sectors in Indonesia or abroad. ${ }^{14}$ The business agents cover a wide range of sectors; wholesale business, retailers and product manufacturers intended for buying and selling activities. ${ }^{15}$ Business agents may join SMEs, MSMEs, or act as resellers. In Indonesia, SMEs and MSMEs play an important role in the development of the country's economy, especially after Indonesia financial crisis. At that time, big companies were collapsed, but MSMEs managed to survive and became the engine that drove the Indonesian economy. ${ }^{16}$

\section{Rights and Obligations of Business Agents}

The Consumer Protection Act applies to business agents. The Consumer Protection Act aims to protect consumers from unusual business agents' behaviour. This rule contains the rights and obligations of business agents as follows:

First, the notion of rights should be understood well. The rights of business agents are regulated in article 6 of the Consumer Protection Act

"The rights of Business Agents are:

a. to receive the payment in accordance with the sales agreement on the conditions and conversion value of the goods and/or services;

b. to obtain legal protection from the consumer's acts of bad faith;

c. to conduct proper self-defense in the legal settlement of the consumer's dispute;

$d$. to rehabilitate its good reputation if legally proven that the consumer's damage is not caused by the goods and/or services purchase;

$e$. to obtain rights as regulated in the other provisions of the law.."

In the Consumer Protection Act, the rights of business agents are related to buying and selling transactions. Then, the obligations of business actors are regulated in article 7 of the Consumer Protection Act;

\footnotetext{
${ }^{13}$ Ibid., pg. . 79

${ }^{14}$ Ahmadi Miru \& Sutarman Yodo, 2004, Hukum Perlindungan Konsumen, PT Raja Grafindo Persada, Jakarta, pg. . 8

${ }^{15}$ Ibid., pg. . 8

${ }^{16}$ Sudaryanto, Ragimun dan Rahma Rina Wijayanti, Strategi Pemberdayaan UMKM Menghadapi Pasar Bebas Asean, https://www.kemenkeu.go.id/sites/default/files/strategi \% 20pemberdayaan \% 20umkm.pdf
} 
"The obligations of Business agents:

a. to act in good faith in conducting the business;

$b$. to provide correct, clear end honest information with regard to the condition and warranty of the goods and/or services and provide an explanation on the use, repair and maintenance;

c. to treat and serve the consumers properly and honestly end non-discriminatively;

$d$. to guarantee the goods and/or services produced and/or traded based on the prevailing quality standard provisions of the goods and/or services;

$e$. to provide the opportunity to the consumers to test and or/try on certain goods and/or services and provide warranty and/or guarantee on the produced and/or traded goods;

f. to provide compensation, redress and/or substitution for the damages caused by the use, consumption and application of the goods and/ or services;

g. to provide compensation, redress and/or substitution if the goods and/or services received or used do not accord with the agreement"

Business agents' obligations include the decent state of transacted goods. They are required to provide authentic information to consumers.

The presence of Consumer Protection Act is expected to act as a benchmark for business agents and consumers so that both parties fulfill each obligation without violating each other's rights. The online buying and selling system has a tendency constructing consumers' losses. Accordingly, the issue of consumer rights is regulated in article 4 of the Consumer Protection Act. As a consequence of consumer rights, the business agents become the subject to an obligation listed in article 7 of the Consumer Protection Act. Obligations of business actors are part of consumer rights. ${ }^{17}$

\section{Selebgram}

Instagram is a popular social media among smartphone users. Instagram is derived from "Insta" which originally comes from "Instant" and "gram" from "telegram." ${ }^{18}$ Instagram was created by Mike Krieger and Kevin Systrom, launched on October 6, 2010. ${ }^{19}$ Celebrity endorsers (selebgram) are born from this social media. Celebrity endorsers (selebgram) has at least 20,000 (twenty thousand) followers. The followers enjoy watching creative content on Selebgram's posts. Thus, a selebgram has an influence on the followers in term of agreeing or disagreeing on certain ideas. For such reason, a selebgram is also referred as an Influencer whose services are used by online business agents to promote certain products. Selebgram trend has become more popular since this social media gain its fame; which triggers the development of many kinds of online shops on Instagram. Today, everyone has a chance to be selebgram as long as having a plentiful number of followers. Selebgram can be adult or kids. Because of its popularity, popular stars even transform into selebgram. The fame and power to be followed by many people make selebgram being trusted to promote a certain product. Promotional activities on Instagram conducted by Selebgram are called endorse and paid promote. ${ }^{20}$

\footnotetext{
${ }^{17}$ Zulham, 2013, Hukum Perlindungan Konsumen, Kencana Prenada Media Group, Jakarta, pg. . 51

${ }^{18}$ Miliza Ghazali, 2016, Buat Duit Dengan Facebook dan Instagram : Panduan Menjana Pendapatan dengan Facebook dan Instagram, Publishing House, Malaysia, pg. . 8

${ }^{19}$ George Berkowski, 2016, How to Build a Billion Dollar App: Temukan Rahasia dari para Pengusaha aplikasi paling sukses di dunia, Gemilang, Tangerang, pg. 91

${ }_{20}$ Chindy Salsabillah, Apa itu selebgram? Ini Dia Asal-Usulnya, ibigacademy.com, https://www.ibigacademy. com/apa-itu-selebgram-asal-usul-endorse/, accessed on October $15^{\text {th }}, 2019$
} 


\section{Tabel I The benefits of using Instagram as a promotional method}

Flexibility Business agents can freely choose which selebgram has suitable Personal Branding in accordance with the product to be sold. The process of collaborating with a selebgram is relatively easy. Personal Branding is usually built by a selebgram to emphasize their image on social media. ${ }^{1}$

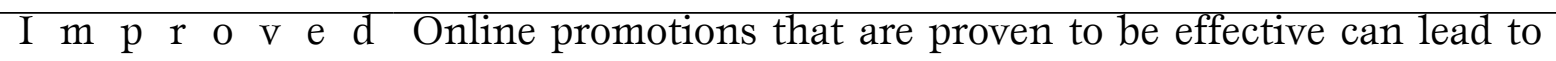
effectiveness $\quad$ product purchasing activities (actions) by followers. ${ }^{2}$

\begin{tabular}{lrl}
\hline Gaining & positive & This happened in one of cities in Indonesia. Product promotion \\
feedback & from & $\begin{array}{l}\text { through food bloggers on Instagram receives good responses from } \\
\text { society }\end{array}$ \\
& & $\begin{array}{l}\text { respondents. } \\
\text { response also gained in other areas.. }\end{array}$
\end{tabular}

The ability to attract Social media has become an effective media for advertisement, Consumers' interest which must be supported by positive words of mouth to attract consumers to make purchases. ${ }^{4}$

In accordance Aside from being the most successful promotional media in with technological Tangerang, Instagram is also a medium for information delivery developments and a means to become more updated. ${ }^{5}$

Source: secondary data that is processed

\section{Online Transaction}

Online transaction activity has become a new trend among Indonesian. According to Bank Indonesia (BI) data, online transactions in Indonesia reached seventy-five trillion rupiah in 2016. ${ }^{21}$ In online transactions, buyers and sellers will not meet face to face. Smartphones enable them to communicate on the details of the offered items. Product promotion on Instagram requires someone in charge of introducing and convincing others to buy the traded items. We are familiar with selebgram, which stands for celebrity instagram (celebrity endorser), who has thousands or millions followers; and there is no qualification for the minimum number of followers to be a selebgram. ${ }^{22}$ Online shops are stores that sell goods and services on the internet in which visitors are able to see the appearance of online shops through their uploaded photos and videos. ${ }^{23}$

The increase in online transactions has driven the growth of online shops. Regrettably, this trend is used by irresponsible people creating an online shop account that sells imitation goods such as fake cosmetics. The possible jeopardy emerges if this fake online shop hires and offers a sum of money to famous celebrities to promote their product. Most selebgram advertise products by stating that they have used the product themselves and have gained a number of benefits from it. The lack of attention for the quality of products promoted by Selebgram affects consumers' losses. The advertisement, which is seemingly able to guarantee the quality of product tempts consumers. Apparently, when

\footnotetext{
${ }^{21}$ Christine Novita Nababan, Belanja Online Masyarakat Indonesia Tembus Rp75 Triliun, https://www.cnnindonesia.com/ekonomi/20170809151902-78-233513/belanja-online-masyarakat-indonesia-tembus-rp75-triliun, accesed on October $15^{\text {th }}, 2019$

22 Anisa Canina Yusra, Selebgram dan Bagaimana Mereka Menghasilkan Uang, https://student.cnnindonesia. com/edukasi/20171220133028-445-263720/selebgram-dan-bagaimana-mereka-menghasilkan-uang/, accesed on September $7^{\text {th }}, 2018$

${ }^{23}$ Irfan Aulia Syaiful, Khairul Rizal, dan Anggit Verdaningrum Kumala Sar. (2017). Proses Pengambilan Keputusan Pembelian di Toko Daring: Peran Faktor Psikologis Persepsi Kualitas Produk dan Tingkat Kepercayaan. Jurnal Penelitian Psikologi, 2(2). doi:http://dx.doi.org/10.21580/pjpp.v2i2.2296
} 
the promotion does not match reality, a selebgram who advertises fake goods, without realizing it, has harmed consumers. ${ }^{24}$ One example is a case of illegal cosmetics, which are endorsed by many famous celebrities and the product becomes famous in several big cities in Indonesia. Because of the massive advertisement, the agents are able to earn three hundred million rupiah per month. These illegal cosmetics are not registered and don't have BPOM numbers. Moreover, these contain harmful ingredients that may cause skin cancer. ${ }^{25}$

\section{Cybercrime Characteristics}

The birth of globalization has improved technology as well as contributed on the rise of more modern crimes. The recent crimes have more dangerous impacts compared to conventional crimes. Conventional crimes commonly use a simple tool, while technology crimes are more complicated and classified as a white color crime. The reason is cybercrime criminals are the experts who are able to run the internet and technology. Apart from sophisticated means, cybercrime is also a transnational crime. ${ }^{26}$

Cybercrime has several characteristics, including ${ }^{27}$ :

1. Illegal or unauthorized acts that occur in a cyber-environment, so the applicable jurisdiction cannot be determined.

2. The Acts are related to the usage of the internet.

3. The incurred losses are greater than conventional crime.

4. The loss can be in the form of material or immaterial, for example, values, time, service fees, self-esteem, the confidentiality of information.

5. The offenders are experts of using the internet or other applications

6. Cybercrime may be performed globally, which means it crosses national borders.

\section{Rules on Obligations of Business Agents}

The law should cover all aspects as outlined in the legislation. The aspects in Education, marriage, companies, cyberspace trade (which has become a recent trend) must be protected by law. Trade has now also experienced growth, especially in the age of today's technology. A person who is willing to make a sale transaction does not require a place, such as a shop or a space inside the market. Having social media allows anyone to sell their products at any time and from any place.

If the conventional method of selling has already been known and has established regulations, online shops which employ social media still require distinctive and effective rules. However, there has been Electronic Information and Transaction Law (hereinafter referred to as ITE Law) which regulates transactions and information in electronic media. The law has not been sufficiently regulated because many other aspects have not been touched by this regulation. One of them is Responsibility for consumer losses. Before going to further discussion, it is important to understand several rules governing the business agents' obligations to provide the truth of information to consumers on definite goods, as follows:

\footnotetext{
${ }^{24}$ Anisatul Ulfa, 2019, Tanggung Jawab Pidana Atas Promosi Produk Di Media Sosial, Universitas Narotama, Surabaya, pg. . 4

${ }^{25}$ Anggi Widya Permani, Sering Di-Endorse Artis Terkenal, Ribuan Kosmetik Ini Ternyata Ilegal, http://kelanakota.suarasurabaya.net/news/2018/213616-Sering-Di-Endorse-Artis-Terkenal, accessed on december $5^{\text {th }}, 2018$

${ }^{26}$ Abdul Manan, 2006, Aspek-Aspek Pengubah Hukum, Kencana, Jakarta, pg. 63-64

${ }^{27}$ Abdul Wahid dan M. Labib, 2005, Kejahatan Mayantara (Cybercrime), Refika Aditama, Bandung, pg. 76
} 
Tabel II rules governing the business agents' obligations to provide the truth of information to consumers on definite goods

\begin{tabular}{|c|c|c|}
\hline Regulation & Article & Contents \\
\hline $\begin{array}{c}\text { Law Number } 8 \text { of } \\
1999 \quad \text { Concerning } \\
\text { Consumer Protection }\end{array}$ & Article 4 letter c & $\begin{array}{l}\text { The rights of consumers : } \\
\text { c. the right to correct, clear and honest } \\
\text { information about the condition and } \\
\text { guarantee of the goods and/orservices; }\end{array}$ \\
\hline & Article 6 letter b & $\begin{array}{l}\text { the rights and obligations of Business } \\
\text { agents : } \\
\text { b. the right of obtaining legal protection } \\
\text { from the acts taken by consumers } \\
\text { without a good intention; }\end{array}$ \\
\hline $\begin{array}{l}\text { Law Number } 32 \text { of } \\
2002 \text { concerning } \\
\text { Broadcasting }\end{array}$ & $\begin{array}{l}\text { Article } 36 \\
\text { section (5) }\end{array}$ & $\begin{array}{l}\text { (5) Broadcast content should not: } \\
\text { a. defamatory, inciting, misleading and } \\
\text { / or lying; }\end{array}$ \\
\hline $\begin{array}{l}\text { Indonesian Broadcasting } \\
\text { C o m m i s s i o n } \\
\text { Regulation number } \\
02 \text { / P / KPI / 03/2012 } \\
\text { concerning Broadcast } \\
\text { Program Standards }\end{array}$ & $\begin{array}{cc}\text { Article } & 58 \\
\text { section } & (4) \\
\text { letter f } & \end{array}$ & $\begin{array}{l}\text { (4) Advertisement broadcast program } \\
\text { shall not: } \\
\text { f. make attempts to hide, mislead, confuse } \\
\text { or deceive the public about the quality, } \\
\text { performance, actual price, and / or } \\
\text { availabilityoftheproductsand/orservices } \\
\text { advertised; }\end{array}$ \\
\hline $\begin{array}{l}\text { Law Number } 11 \text { of } 2008 \\
\text { Regarding Electronic } \\
\text { Information and } \\
\text { Transactions }\end{array}$ & $\begin{array}{l}\text { Article } 28 \\
\text { section (1) }\end{array}$ & $\begin{array}{l}\text { Any personwhoknowinglyandwithout } \\
\text { authority disseminates false and } \\
\text { misleading information resulting } \\
\text { in consumer loss in Electronic } \\
\text { Transactions. }\end{array}$ \\
\hline
\end{tabular}

Source: primary data that is processed

Indonesia has several laws that require sellers or producers to provide honest information to consumers. In addition, there is also article 28 section (1) which regulates transactions through electronic media. But those regulations are not sufficient because many other aspects have not been regulated. For example, the widespread use of Selebgram' endorsement or paid promote services as a promotional media. A selebgram uploads videos or photos on instagram for promoting the products. If the products are bad or fake, such promotion will have misleading features, which are then re-uploaded by the online shop accounts. So, who will be responsible for the consumers' losses? Selebgram who creates the content or online shop that uploads on social media? The firm rules that govern this haven't been stipulated so far.

When Indonesia needs specific regulation on cybercrime, our neighboring country, Malaysia, has stipulated the essential e-commerce regulation. Malaysia has established several laws to control cybersecurity threats; one of them is about electronic commerce: ${ }^{28}$

\footnotetext{
${ }^{28}$ Muhammad Adnan Pitchan Dan Siti Zobidah Omar. (2019). Dasar Keselamatan Siber Malaysia: Tinjauan Terhadap Kesedaran Netizen Dan Undang-Undang. Jurnal Komunikasi (Malaysian Journal of Communication), 35(1). https://doi.org/10.17576/JKMJC-2019-3501-08
} 
1. The Communications and Multimedia Act 1998

2. The Computer Crimes Act 1997

3. Electronic Commerce Act 2006 which helps the government in reducing cybercrime in Malaysia

4. The Personal Data Protection Act 2010 which is used to protect personal data from being commercially abused by certain parties

5. Consumer Protection Act 1999 (Amendment 2010) that protects Internet users from misleading advertisements.

The governments of European countries have realized that economic development in the digital age is very important. However, they are also aware of the free flow of personal data becomes the impending danger to European which tends to be misused in internet transactions. The governments must protect this data from being abused by irresponsible parties, such as being exploited in the trials of newly launched products. Thus, they balance the free flow of data by respecting Individual privacy and tightening the security. This will be crucial to the success of a dynamically connected European economy. ${ }^{29}$

One of the previous researches studied discusses press responsibility on social media. It states that the press is responsible for its content on social media. For that reason, the Press should be more careful in delivering the news. News must be based on facts and avoid insulting $S A R A$ (ethnic groups, religion, race and group-based interest). ${ }^{30}$

Another study concludes that a Selebgram is responsible for the content of Endorsement and Paid promote which are made. So that if consumers suffer losses due to the content, selebgram can be held responsible. ${ }^{31}$ Then, what if the content made by Selebgram is uploaded again by online shop account owners?

Before discussing further, it is necessary to understand that a Selebgram is different from a Brand Ambassador. A brand ambassador is a representative of a product and the brand name is attached to this Ambassador 24 hours a day. All kinds of Ambassador's activities related to the brand are legally written on the contract. In contrast to a selebgram who employs instagram, their activities are regulated by the ITE Law, the Consumer Protection Act and the Broadcasting Law. To get more sufficient description, the following is the list of differences between selebgram and Ambassador

\begin{tabular}{lll}
\multicolumn{3}{c}{ Tabel III Selebgram and Brand Ambassador's dissimilarities } \\
\hline & \multicolumn{1}{c}{ Brand ambassa- } & Selebgram \\
\hline dor & Television and radio & Instagram \\
\hline Media & Broadcasting Law and & ITE Law \\
\hline Regulation & Indonesian Broadcasting \\
& Commission Regulation
\end{tabular}

\footnotetext{
${ }^{29}$ Laurence Kalman, New European Data Privacy And Cyber Security Laws - One Year Later. Communications Of The Acm, vol. 62 no. 4 edisi april 2019, pg. . 39

${ }^{30}$ Nynda Fatmawati Octarina., op.cit, pg. . 207-215

${ }^{31}$ Anisatul Ulfa, op.cit., pg. . 57
} 


\begin{tabular}{|c|c|c|}
\hline Sanction & Administrative & Criminal sanctions \\
\hline What to be displayed & $\begin{array}{l}\text { Follow what has been ar- } \\
\text { ranged }\end{array}$ & $\begin{array}{l}\text { Selebgram receives the general in- } \\
\text { formation of the product and de- } \\
\text { velops it freely }\end{array}$ \\
\hline Manufacturer & listed & not listed \\
\hline $\begin{array}{l}\text { BPOM number and } \\
\text { product ingredients }\end{array}$ & listed & not listed \\
\hline $\begin{array}{l}\text { Brand name which } \\
\text { is attached at one } \\
\text { time }\end{array}$ & $\begin{array}{l}\text { Only one brand is at- } \\
\text { tached to BA }\end{array}$ & more than one endorsements \\
\hline
\end{tabular}

Source: secondary data that is processed

As explained earlier, Selebgram provides services to promote online shop products. In return, the online shop provides a payment that has been approved by both parties. Each selebgram put up different rates, starting from IDR 800,000 to IDR 22,000,000.00. The phenomenon of selebgram does not only emerge in Indonesia but also abroad. The following are differences between Indonesian and foreign selebgram in general:

\begin{tabular}{|c|c|c|}
\hline & Indonesia & Abroad \\
\hline Rate per upload & $\begin{array}{l}\text { Non-celebrities' rate are } \\
\text { around Rp. } 800,000.00 \text { to } \\
\text { Rp 4,000,000.00 (loop.co.id, } \\
2019)^{6} \\
\text { Popular celebrities' rate are } \\
\text { around Rp. 6,000,000.00 to } \\
\text { Rp 22,000,000.00 (Putri }{ }^{2017) 7}\end{array}$ & $\begin{array}{l}\text { Celebrities' rate } \\
\text { around } \$ 370,000.00 \text { to } \\
\$ 550,000.00\left(\mathrm{Putri}^{2017}\right) .^{8}\end{array}$ \\
\hline $\begin{array}{l}\text { The method of propos- } \\
\text { ing business coopera- } \\
\text { tion (Utami, 2019) }\end{array}$ & $\begin{array}{l}\text { In a case, an influencer } \\
\text { sent a short message via } \\
\text { Instagram Direct Message } \\
\text { (DM) with less informa- } \\
\text { tive introductions. }\end{array}$ & $\begin{array}{l}\text { In a case, one foreign } \\
\text { influencer introduced } \\
\text { him(her)self before } \\
\text { writing cooperation pro- } \\
\text { posal. After that, this } \\
\text { influencer explained the } \\
\text { details of the contents } \\
\text { that will be provided. }\end{array}$ \\
\hline
\end{tabular}

Source: secondary data that is processed 
Criminal Responsibility for contents made by selebgram and re-uploaded by business agents on their accounts

\section{Responsibility in Criminal Law}

Responsibility is a circumstance in which a person is obliged to bear the whole thing, which means if something happens, one can be sued, blamed, or prosecuted ${ }^{32}$. Two types of Responsibility are Responsibility based on fault and absolute Responsibility. The latter is an act that causes consequences considered as damaging by lawmakers and related to cause and effect. ${ }^{33}$ Absolute Responsibility in primitive societies did not oblige individuals to implement certain acts that prevented them from things that could harm others, and the sanctions were imposed on cases where the perpetrator did not fulfill the precautionary principles. ${ }^{34}$

Criminal law is one of applicable law in a country, regulating and determining ${ }^{35}$ :

1. The deedswhichare prohibited and forbidden.This regulation is followed by threats or sanctions for the wrongdoers.

2. When and in what cases a person who violates the prohibition can be sentenced to the criminal sanction that has been threatened.

3. The methods to carry out the punishments on someone who violates.

Several features in a criminal act are as follows ${ }^{36}$ :

1. The actions consisting of behavior and consequences.

2. The circumstance or thing which is followed the actions.

3. Additional circumstances that burdens the punishment.

4. Objective elements which are against the law.

5. Subjective elementswhich are against the law.

The three behaviors in Criminal act are delictum commissionis, delictumommissionis, Delictacommissionis per omnissionemcommiss. Delictumcommissionis or active (positive) behavior occurs when someone's actions are in accordance with the prerequisite offense. Delictumommissionis or passive (negative) behavior occurs when a person does not obey the order in a law. Delictacommissionis per omnissionemcommiss means a criminal act may occur because of negative behavior. ${ }^{37}$

Moeljatno classifies three behaviors which are not supported by the will and not realized by the act of will ${ }^{38}$ :

1. A completely passive and undesirable physical behavior; the person is under pressure, overmatch, or compulsion.

2. Reflex movements

3. Physical behavior that manifest due to unconsciousness, such as delirium, hypnosis, and drunkenness.

In taking Responsibility for actions, a person must have the following abilities ${ }^{39}$ :

1. The reason factor means a person should be able to distinguish whether the deeds are good or bad, break the law or not, as well as, permitted or not.

\footnotetext{
${ }^{32}$ HasanAlwi, KamusBesarBahasa Indonesia, 3th edition, BalaiPustaka, Jakarta, 2002

${ }^{33}$ Jimly Asshiddiqie, Ali Safa'at, Teori Hans KelsententangHukum, Konstitusi Press, Jakarta, 2006, pg. . 61

${ }^{34}$ Hans Kelsen, General Theory of Law and State, Russell \&Russel, New York, 1961, pg. .98

${ }^{35}$ Moeljatno, Asas-asasHukumPidana, RinekaCipta, Jakarta, 2002, pg. .1

${ }^{36}$ Moeljatno, Asas-asasHukumPidana, 2nd edition, BinaAksara, Jakarta, 1984, pg. . 63

${ }^{37}$ NyndaFatmawatiOctariana, PidanaPemberitaan Media Sosial, Setara Press, Malang, 2018, pg. . 145

${ }^{38}$ Moeljatno, op.cit.,Pg. . 86

${ }^{39}$ Moeljatno, Asas-asasHukumPidana, 2nd edition, BinaAksara, Jakarta, 1984, pg. . 165
} 
2. Feeling and intention factors means a person is able to determine his/her will according to the conviction of whether or not the deeds are good or bad, allowed or forbidden. A person who is unable to determine his/her will based on the conviction means that he/she is without fault; such a person cannot be held accountable. It is in accordance with Article 44 of Criminal Code which stipulates that the condition must be caused by a disability or illness in the body.

Basically, punishment for a criminal act has the following objectives:

1. To deliver the fear effect to society so that they will not perform bad behavior.

2. To educate people who have performed bad behaviors so that they can return to society.

The wrongdoers can be punished if they have committed a crime that is in accordance with the elements written in the law. The wrongdoers will be held accountable if their actions are proven to have violated the law, but only those who have the ability to be responsible will be held accountable. Responsibility is part of a person's mental and intellectual considerations. This is a reflection of human behavior which is indirectly related to mental control. ${ }^{40}$

The principles of liability in law are as follows ${ }^{41}$ :

1. The liability based on fault principle.

Fault liability or liability based on fault states that a person can be held accountable if the mistake element is found in the actions.

2. The presumption to always be responsible principle

This principle states that the defendant is always responsible (presumption of liability principle); this is applied until the defendantis able to prove his/herinnocence. ${ }^{42}$ 3 . The presumption to not always be a responsible principle.

This principle states that the defendant is not always responsible; this principle is only known in a very limited scope of consumer transactions such as the law of carriage.

4. The principle of absolute liability

This is the principle of Responsibility without error and exception. In this principle, there is no possibility to free oneself from Responsibility, unless there is a loss inflicted by the fault of the injured party. ${ }^{43}$

5. The limitation of liability principle

The limitation of liability principle is commonly used by business agents to be included as an exoneration clause in the standard agreement they make.

According to Moeljatno, it is impossible for a person to be held responsible (to be punished) if he/she does not commit a criminal act. Even if someone commits a criminal act, he/she is not always convicted. ${ }^{44}$

The fault factors in criminal responsibility are as follows:

1. Committing a criminal act

The criterion for someone to have committed a criminal act is whether that person's act, action, deeds or activity has been regulated in law. If that person violates the existed regulation, it can be concluded that the person has committed a criminal act.

\footnotetext{
${ }^{40}$ MansyurEfendi, Dimensi/ DinamikaHakAsasiManusiadalamHukumNasionaldanInternasional, Ghalia Indonesia, Jakarta, 1994, pg. . 121

${ }^{41}$ Shidarta, HukumPerlindunganKonsumen Indonesia (EdisiRevisi),GramediaWidiasarana Indonesia, Jakarta, 2006, pg. .73-79

${ }^{42}$ E. Suherman, MasalahTanggungJawabPada Charter PesawatUdaradanBeberapaMasalah Lain dalamBidangPenerbangan (Kumpulan Karangan), Cet.II, Alumni, Bandung, 1979, pg. 21

${ }^{43}$ Shidarta, op.cit., h. 23

${ }^{44}$ Ibid., pg. 67
} 
If that person's act, action, deeds or activity has not been specified in the law, he/she has not committed a criminal act. This is known as the legality principle. ${ }^{45}$

2. Age in Criminal Responsibility

A person is able to take Responsibility when reaching a certain age. Article 9 paragraph (1) of Compilation of Islamic Law stipulates thatadult is a person who has reached the age of 21; Article 47 paragraph (1) of Law no. 1 of 1974 concerning Marriage regulates that adult is a person who has reached the age of 18; Article 1 paragraph (1) of Law no. 23 of 2003 concerning Child Protection regulates that the adult is a person who has reached the age of 18; Article 45 of the Criminal Code regulates that an adult is a person who has reached the age of 16; Article 4 of Law No. 3 of 1997 on Juvenile Court stipulates that adult is a person who has reached the age of 21 .

3. Deliberately (dolus) or negligence (culpa)

a. Deliberately (dolus / opzet)

Opzet (Dutch) in English is called intention which can be interpreted as intentionally or deliberately. In Criminal Code, not all articles clearly state the phrase "deliberately", but behaviors or activities with a deliberate intention like in the phrases: "with the intention"; "by knowing"; "wishing"; "with a plan of"; "with the intention of"; "by force"; "instigate"; or "make a fake letter".

The meaning of wishing can be addressed to the actions which are prohibited, its consequences which are forbidden, and a situation which constitutes an element of criminal act. Formal intention is the intentions aimed only at the actions and material intention is aimed at consequences. ${ }^{46}$

The followings are the theory related with the term "deliberately":

(1) Wills Theorie

This theory is composed by Von Hipel and Simon. Based on this theory, a person is said to have committed deliberate actions when he/she wishes to commit the criminal act. This person is also ready to bear all the consequences of the crime that has been committed.

(2) Knowledge or visualization theory (VoorstellingTheorie)

This theory is supported by Frank. According to this theory, a person is said to have committed deliberate actions when he/she knows what he/she is doing and the consequences of that action. The wrongdoer does not want to commit the criminal act, but still commits the crime so that the consequences prohibited by law occur. ${ }^{47}$

b. Negligence (Culpa)

Negligencehappenswhen the wrongdoerdoes notintend toviolate the provisions of thelaw, butdisregards the prohibition. Thus, the wrongdoer is considered negligent or careless in carrying out these actions. In his/her negligence, the defendant neglects the prohibition so that he/she is not careful in committing objective causal acts which leads to forbidden circumstances. In legal science, the technical meaning of culpa is a kind of error as a result of not being careful so that something happens accidentally. ${ }^{48}$

Vos mentions two elements of culpa:

\footnotetext{
${ }^{45}$ DidiekEndroPurwoleksono, HukumPidana, Airlangga University Press, Surabaya, 2014,pg. 63-64

${ }^{46}$ Ibid., pg. 69

${ }^{47}$ Ibid., pg. $69-70$

${ }^{48}$ Kansil, Pokok-pokokHukumPidana, PradnyaParamita, Jakarta, 2004, pg. 54-55
} 
(1) Predictability of consequences

(2) Not being careful about what is done or not done

Negligence and deliberation have several similarities ${ }^{49}$ :

(1) The existence of a criminal act

(2) Above a certain age and the ability to be responsible

(3) The absence of excuses

(4) Equally punishable by punishment.

Van Hamel states that two conditions indicate that the defendant disregards the objects protected by law ${ }^{50}$ :

(1) Failure to predict as required by law. This requirement has two possibilities:

a. The defendant thinks that the consequences will not occurbecause of his/her actions.

Hence, the fault lies in the wrong thinking or views that should be eliminated.

b. The defendant has absolutely no thought that the prohibited consequences ascend as a result of his/her actions. In this case, the fault lies in not having any thought that the result will arise, so that it is dangerous.

(2) Not exercising the discretion as required by law. According to Van Hamel, this is an act of not conducting research, wisdom, skill or preventive efforts in acting. Hence, the object of observation and judgment is not in the mind of the defendant, but in behavior. The standards are determined by state statutory regulations either written or not. This condition is important in order to determine the negligence that the prosecutor must prove. This second condition follows the first condition, if the first condition exists, then automatically the second condition also exists. Whoever does it without being careful; he also does not expect the result of his/her actions.

Judging from the perpetrator's awareness, there are two kinds of negligence ${ }^{51}$ :

(1) Conscious negligence (bewusteschuld)

The perpetrator imagines or predicts the possible consequences that accompany his/her actions, even though he/she has tried to prevent the consequences.

(2) Unconscious negligence (onbewusteschuld)

The perpetrator does not imagine and predict the possibility of a consequence accompanying his/her actions which should be imagined or predicted.

The level of negligence is divided into two as follows ${ }^{52}$ :

(1) Heavy negligence (culpa lata)

In Dutch language, it is called merlijkeschuld or grove schuld. The experts state that this negligence is a "crime of negligence" as contained in articles 188, 359, 360 of Criminal Code.

\footnotetext{
${ }^{49}$ DidiekEndroPurwoleksono, op.cit., pg. 73

${ }^{50}$ Moeljatno, op.cit., 2015, pg. 218-221

${ }^{51}$ Ibid., pg. 210

${ }^{52}$ Ibid.
} 
(2) Light negligence

In Dutch language, it is referred to lichteschuld. The experts state that this negligence is in the violation of book III of Criminal Code.

4. There is no mercyexcuse

Indonesian criminal law also defines circumstances that cause perpetrators to not be held accountable. ${ }^{53}$ The negative formulation is closely related to the repressive function of criminal law and the accountability of a person in criminal law. Hence, the concept of criminal Responsibility is the conditions used to sentence people who commit criminal acts. ${ }^{54}$

\section{The Business Agents' Responsibility}

There is a term 'legal subject' in law; the legal subject can be a human being and others based on the needs of society, which is recognized by law as supporting rights and obligations. ${ }^{55}$ If the law recognizes legal subjects of individual and legal entity, then this principle is alsoapplied onsocial media. Social media is operated by a person or individual and this person may also represent a certain group. Hence, the legal subject is someone who owns an Instagram account or acts as an online-based business agents.

Those who provide services should not only seek profit but also deliver dedication to other humans. They must also be responsible, bybearing all risks of the service. Negligence in carrying out a profession harmsthemselves or others and becomes sin against God. ${ }^{56}$

The abundanceactive Instagram users make this a great place for marketing goods and services; even the users don't realize of seeing an advertisement on it. ${ }^{57}$ Henceforth, many entrepreneurs are interested in offering their products through promotions using selebgramservices. Moreover, selebgram have more influence because they are followed by various groups. Business agents offer collaboration to selebgram to promote their products. Selebgramare then asked to provide a review of the product by consuming or using it first.

The main task of selebgram is to create a good impression on the advertised product which leads to a positive attitude of consumers. This is what concerns the author of this research. Knowing the main task of selebgram,they potentiallyexaggerate the information conveyed to their followersto make the product looks good in the eyes of consumers. Consumers are tempted by selebgram promotions that seem to guarantee the product quality. In fact, there is no guarantee that the advertised product has an official permit from the Food and Drug Administration. Unconsciously, selebgramsinstigatethe consumers to suffer losses. ${ }^{58}$ In previous studies, it has been explained that selebgram are responsible for what is uploaded on their personal accounts. ${ }^{59}$ However, what is about business agent who also provides information to selebgram? Are they also responsible for promotions carried out by selebgram?

The laws and regulations governing business agents are contained in Law Number 8 of 1999 on Consumer Protection. Article 7 letter b of Consumer Protection Law states the obligations of business agents towards consumers, as follows:

\footnotetext{
${ }^{53}$ Andi Zaenal Abidin, Hukum Pidana I, Sinar Grafika, Jakarta, 1983, pg. 260.

${ }^{54}$ Choerul Huda, Dari Tiada PidanaTanpa Kesalahan MenujuKepada Tiada Pertanggungjawaban tanpa Kesalahan, Kencana, Jakarta, 2006, pg. 62

${ }^{55}$ H. Setiyono, 2003, KejahatanKorporasi, Bayumedia, Malang, pg. . 2

${ }^{56}$ Abdulkadir Muhammad, 2011, EtikaProfesiHukum, Citra AdityaBakti, Bandung, pg. . 60

${ }^{57}$ HandokoHendroyono, 2012, Brand Gardener, Literati, Tangerang, pg. . 283

${ }^{58}$ AnisatulUlfa, op.cit.,pg. . 5

${ }^{59}$ Ibid.,pg. . 57
} 
"The obligations of business agents shall be:

b. providing correct, clear and honest information about the condition and guarantee of goods and/or services and providing explanation about uses, repair and maintenance;"

As previously explained, business agents and selebgram make an agreement on what to promote. Business agents as product owners potentially provide false information to selebgram to create good impression of the product. Meanwhile, it is clearly stated in Consumer Protection Law that this act is not justified. Then, the incorrect information is published by Selegram. Thus, consumers suffer losses.

Law Number 32 of 2002 on Broadcasting regulates selebgram' sposts. As stated in article 36 paragraph (5) of the Broadcasting Law:

"Broadcast contents shall not:

a. contain slanderous, inciting, misleading, and/or false materials;"

There are two phrases in this article which are almost similar but actually different; "misleading" and "false". The definition of misleading according to Indonesia Dictionary is 'to lead to the wrong path', 'to lead astray (wrong way)', 'to cause wrong' ${ }^{60}$. For example, the actual product width is $10 \mathrm{~cm}$ but the width is informed as $15 \mathrm{~cm}$. Meanwhile, the definition of false according to Indonesia Dictionary is 'not in accordance with actual things (circumstances and so on)', 'lies', 'not the truth', 'fake' ${ }^{61}$. For example, a business agents or Selebgram provide information that a product contains a real fruit juice, but in reality, the product does not contain fruit juice but chemical flavorings. In this case, selebgram should also be responsible, because before spreading information, they should investigate the truth, at least reading the ingredient list written on the product packaging. On the other hand, selebgram are only intermediary to convey the information. If business agents provide false information, the promotions will also be incorrect. Therefore, business agents are also responsible for the information relayed by selebgram. In addition, business agents can also be subject to this article if they upload a photo or video that has been posted by selebgram. This article emphasizes "broadcast content", so any one who broadcasts can be subjected by that article. This article is strengthened by Regulation of Indonesian Broadcasting Commission which also stipulates the prohibition of misleading and deceptive advertising content. This is listed in article 58 paragraph (4) letter $\mathrm{f}$ of Indonesian Broadcasting Commission Regulation number 02 / P / KPI / 03/2012 on Broadcast Program Standards.

In this modern era, communication is carried out by utilizing electronic technology, including agreements between business agents and selebgram. The communication may use direct message. This means that these activities are included in electronic transactions which are specifically regulated in Law Number 11 of 2008 on Electronic Information and Transactions. Related to this, article 28 paragraph (1) of Electronic Information and Transactions Law stipulates

"(1)Any person who knowingly and without authority disseminates false and misleading information resulting in consumer loss in Electronic Transactions."

Basically, Electronic Information and Transactions Law is divided into 2 parts, the first part discusses electronic information and transactions. The second part regulates

\footnotetext{
${ }^{60}$ Ministry of Education and Culture, https://kbbi.kemdikbud.go.id/entri/menyesatkan, accessed on September$2^{\text {nd }}, 2019$

${ }^{61}$ Ministry of Education and Culture, https://kbbi.kemdikbud.go.id/entri/bohong, accessed on September $2^{\text {nd }}$, 2019
} 
prohibited acts. ${ }^{62}$ Article 28 paragraph (1) is part of the article which regulates prohibition. To see the validity of this article, it must be described through the elements contained in it.

a. Any person means everyone who uses the internet, including business agents.

$b$. Knowingly and without authority means violates the rights of others, consumer rights, which are guaranteed in article 4 letter $c$ of the Consumer Protection Law "the right to correct, clear and honest information about the condition and guarantee of the goods and/or services;". Business agents will be sentenced by this article if conveying false and misleading product information to selebgram.

c. Disseminates false and misleading information. The word "and" indicates that the two elements must be fulfilled. Disseminates false means that it is not in accordance with the real thing/situation and Misleading information means causing someone to have the wrong understanding. Selebgramsmay receives false and misleading information on the products obtained from business agents.

d. Resulting in consumer loss in Electronic Transactions,

Selebgrampostproduct promotion on their account and consumers are interested in buying such a product. In the end, consumers suffer losses.

Indirectly, business agents are also responsible for the losses suffered by consumers. The act of business agents who deliver false information to selebgram in the initial agreement leads to consumer losses. In this case, business agents may:

1. Deliberately deliver false and misleading information to selebgram to create a good impression on the product. According to Will's theory, business agents wish to commit the crime. Hence, business agents are ready to bear all the consequences of the committed crime.

2. According to Knowledge theory, business agents do not have the intention to provide false and misleading information, but they still commit criminal act which causes the consequences prohibited by law.

3. Business agents commit conscious negligence (bewusteschuld), which means the actor can predict the possible consequences of the actions.

4. Business agents commit unconscious negligence (onbewusteschuld), which means that the business agents do not imagine and predict the possible consequences that should have been imagined or predicted. The severity of the punishment is determined by how much harm the consumer suffers.

\section{CONCLUSION}

Business agents are also responsible for distributing misleading promotion content by clebrity endorsers. Although the promotion content is made by a selebgram and does not involve business agents in this making process, business agents should still be asked for Responsibility because their involvement in guiding the information which can detrimental to the consumers. This rule is based on Article 28 section (1), which states "any person".

\footnotetext{
${ }^{62}$ NyndaFatmawatiOctarina., op.cit, pg. . 206
} 


\section{RFFERENCES}

\section{Books}

Abdul Manan, (2006), Aspek-Aspek Pengubah Hukum, Kencana, Jakarta

Abdulkadir Muhammad, (2011), Etika Profesi Hukum, Citra Aditya Bakti, Bandung

Abdul Wahid dan M. Labib, (2005), Kejahatan Mayantara (Cybercrime), Refika Aditama, Bandung

Ahmadi Miru \& Sutarman Yodo, (2004), Hukum Perlindungan Konsumen, PT Raja Grafindo Persada, Jakarta

Andi Zaenal Abidin, (1983), Hukum Pidana I, Sinar Grafika, Jakarta

Budi Suhariyanto, (2014), Tindak Pidana Teknologi Informasi (Cybercrime), PT Raja Grafindo Persada, Jakarta

Christian Fuchs, (2014), Sosial Media: A Critical Introduction, British Library

Choerul Huda, (2006), Dari Tiada Pidana Tanpa Kesalahan Menuju Kepada Tiada Pertanggungjawaban tanpa Kesalahan, Kencana, Jakarta

Didiek Endro Purwoleksono, (2014), Hukum Pidana, Airlangga University Press, Surabaya

Didik M. Arief Mansur dan Elisataris Ghultom, (2005), Cyber Law-Aspek Hukum Teknologi Informasi, Refika Aditama, Bandung

E. Suherman, (1979), Masalah Tanggung Jawab Pada Charter Pesawat Udara dan Beberapa Masalah Lain dalam Bidang Penerbangan (Kumpulan Karangan), Cet. II, Alumni, Bandung

E Sumaryono, (1995), Etika Profesi Hukum: Norma-norma bagi Penegak Hukum, Kanisius, Yogyakarta

George Berkowski, (2016), How to Build a Billion Dollar App: Temukan Rahasia dari para Pengusaha aplikasi paling sukses di dunia, Gemilang, Tangerang

Hans Kelsen, (1961), General Theory of Law and State, Russell \& Russel, New York Hasan Alwi, (2002), Kamus Besar Bahasa Indonesia, Ed. Ke-3, Balai Pustaka, Jakarta H. Setiyono, (2003), Kejahata Korporasi, Bayumedia, Malang

Jimly Asshiddiqie, (2006), Ali Safa'at, Teori Hans Kelsen tentang Hukum, Konstitusi Press, Jakarta

Kansil, (2004), Pokok-pokok Hukum Pidana, Pradnya Paramita, Jakarta

Mansyur Efendi, (1994), Dimensi/ Dinamika Hak Asasi Manusia dalam Hukum Nasional dan Internasional, Ghalia Indonesia, Jakarta Miliza Ghazali, (2016), Buat Duit Dengan Facebook dan Instagram : Panduan Menjana Pendapatan dengan Facebook dan Instagram, Publishing House, Malaysia

Moeljatno, (1984), Asas-asas Hukum Pidana, Cetakan Kedua, Bina Aksara, Jakarta

Moeljatno, (1987), Azaz-azaz Hukum Pidana, Bina Aksara, Jakarta

Moeljatno, (2002), Asas-asas Hukum Pidana, Rineka Cipta, Jakarta 
Moeljatno, (2015), Asas-asas Hukum Pidana, PT. Rineka Cipta, Jakarta

Morisan, (2010), Periklanan komunikasi pemasaran terpadu, Penerbit kencana, Jakarta

Niniek Suparni, (2009), Cyberspace Problematika dan Antispasi Pengaturannya, Sinar Grafika, Jakarta

Nynda Fatmawati Octarina, (2018), Pidana Pemberitaan Media Sosial, Setara Press, Malang

Shidarta, (2006), Hukum Perlindungan Konsumen Indonesia (Edisi Revisi), Gramedia Widiasarana Indonesia, Jakarta

Zulham, (2013), Hukum Perlindungan Konsumen, Kencana Prenada Media Group, Jakarta

\section{Articles in academic journals:}

Andreas M. Kaplan, (2010), User of The World, Unite! The Challenges and Opportunities of Sosial Media, Business Horizons, vol. 53 no. 1, page 59-68

Bagas Aji Pamungkas, Siti Zuhroh, (2016), Pengaruh Promosi Di Media Sosial Dan Word Of Mouth Terhadap Keputusan Pembelian (Studi Kasus Pada Kedai Bontacos, Jombang), Komunikasi, vol. 10 no.2, page. 157

Dita Rachmawati, Dini Salmiyah Fithrah Ali, (2018), Analisis Kriteria Personal Branding Selebgram Non Selebriti (Studi Deskriptif Kualitatif Akun Instagram @Lippielust), Komunikasi, vol. 12 no.1, page. 24

Laurence Kalman, (2019), New European Data Privacy And Cyber Security Laws - One Year Later. Communications Of The Acm, vol. 62 no. 4, page. 39

M. Fariz Syahbani1, Arry Widodo, (2017), Food Blogger Instagram: Promotion Through Social Media, Jurnal Ecodemica, vol.1 no.1, page. 55

Puslitbang Hukum dan Peradilan (Agency for Research and Development and Education and Training in Law and Justice) Supreme Court of Indonesia, (2004), Naskah Akademis Kejahatan Internet (Cybercrime), page. 4

Tanty Dewi Permassanty, Muntiani, (2018), Strategi Komunikasi Komunitas Virtual Dalam Mempromosikan Tangerang Melalui Media Sosial, Jurnal Penelitian Komunikasi, vol. 21 no.2, page. 184

Zulia Khairani, Efrita Soviyant, Aznuriyandi, (2018), Efektivitas Promosi Melalui Instagram Pada Umkm Sektor Makanan Dan Minuman Di Kota Pekanbaru, Jurnal Benefita, vol.3 no.2, page. 246

\section{Thesis/Disertations}

Anisatul Ulfa, (2019), Tanggung Jawab Pidana Atas Promosi Produk Di Media Sosial, Skripsi, Fakultas Hukum, Univ. Narotama, Surabaya.

\section{Articles on online academic journals}

Irfan Aulia Syaiful, Khairul Rizal, dan Anggit Verdaningrum Kumala Sar. (2017). Proses Pengambilan Keputusan Pembelian di Toko Daring: Peran Faktor Psikologis Persepsi Kualitas Produk dan Tingkat Kepercayaan. Jurnal Penelitian Psikologi, 
2(2). doi:http://dx.doi.org/10.21580/pjpp.v2i2.2296

Muhammad Adnan Pitchan Dan Siti Zobidah Omar. (2019). Dasar Keselamatan Siber Malaysia: Tinjauan Terhadap Kesedaran Netizen Dan Undang-Undang. Jurnal Komunikasi (Malaysian Journal of Communication), 35(1). https://doi. org/10.17576/JKMJC-2019-3501-08

\section{Laws and Regulations}

Law no. 8 of 1999 concerning Consumer Protection (State Gazette of the Republic of Indonesia of 1999 Number 42. Supplement to the State Gazette of the Republic of Indonesia Number 3821)

Law Number 32 of 2002 concerning Broadcasting (State Gazette of the Republic of Indonesia of 2002 Number 139. Supplement to the State Gazette of the Republic of Indonesia Number 4252)

Law Number 11 of 2008 concerning Electronic Information and Transactions (State Gazette of the Republic of Indonesia of 2008 Number 58. Supplement to the State Gazette of the Republic of Indonesia Number 4843)

Indonesian Broadcasting Commission Regulation number 02 / P / KPI / 03/2012 concerning Broadcast Program Standards

\section{Laws and Regulations of The Republic of Malaysia}

The Communications and Multimedia Act 1998

The Computer Crimes Act 1997

Electronic Commerce Act 2006

The Personal Data Protection Act 2010

Consumer Protection Act 1999 (Amendment 2010)

\section{Websites}

Aditya Widya Putri, Para Selebgram dan Pundi-pundi Uang, https://tirto.id/paraselebgram-dan-pundi-pundi-uang-csuF, accessed on september $1^{\text {st }}, 2019$

Anggi Widya Permani, Sering Di-Endorse Artis Terkenal, Ribuan Kosmetik Ini Ternyata Ilegal, http://kelanakota.suarasurabaya.net/news/2018/213616-Sering-DiEndorse-Artis-Terkenal, accessed on december $5^{\text {th }}, 2018$

Anisa Canina Yusra, Selebgram dan Bagaimana Mereka Menghasilkan Uang, https:// student.cnnindonesia.com/edukasi/20171220133028-445-263720/selebgramdan-bagaimana-mereka-menghasilkan-uang/, accessed on September $7^{\text {th }}, 2018$

Chindy Salsabillah, Apa itu selebgram? Ini Dia Asal-Usulnya, ibigacademy.com, https:// www.ibigacademy.com/apa-itu-selebgram-asal-usul-endorse/, accessed on October $15^{\text {th }}, 2019$

Christine Novita Nababan, Belanja Online Masyarakat Indonesia Tembus Rp75 Triliun, https://www.cnnindonesia.com/ekonomi/20170809151902-78-233513/ belanja-online-masyarakat-indonesia-tembus-rp75-triliun, accessed on October $15^{\text {th }}, 2019$

Ministry of Education and Culture, https://kbbi.kemdikbud.go.id/entri/menyesatkan 
Ministry of Education and Culture, https://kbbi.kemdikbud.go.id/entri/bohong

loop.co.id, Penghasilan Selebgram Tanah Air Ini Bikin Tercengang, Siapa Saja Sih?, https://loop.co.id/articles/penghasilan-selebgram-tanah-air/full, accessed on September $1^{\text {st }}, 2019$

Silfa Humairah Utami dan Amertiya Saraswati, Beda Influencer Luar Negeri dan Lokal Tawarkan Kerjasama, Bikin Menohok, https://www.suara.com/ lifestyle/2019/04/02/114436/beda-influencer-luar-negeri-dan-lokal-tawarkankerjasama-bikin-menohok, accessed on September $1^{\text {st }}, 2019$

Sudaryanto, Ragimun dan Rahma Rina Wijayanti, Strategi Pemberdayaan UMKM Menghadapi Pasar Bebas Asean, https:/www.kemenkeu.go.id/sites/default/ files/strategi \% 20pemberdayaan \% 20umkm.pdf 